\title{
The relationship between environmental variation and species abundance in shrimp community (Crustacea: Decapoda: Penaeoidea) in south-eastern Brazil
}

\author{
ANTONiO L. CASTILHO ${ }^{1}$, MARCIO R. PIE ${ }^{2}$, ADILSON FRANSOZO ${ }^{1}$, ALLYSSON P. PINHEIRO ${ }^{1}$ \\ AND ROGÉRIO C. COSTA ${ }^{1,3}$ \\ ${ }^{1}$ NEBECC (Group of Studies on Crustacean Biology, Ecology and Culture), Departamento de Zoologia, Universidade Estadual \\ Paulista, 18618-ooo, Botucatu, São Paulo, Brazil, ${ }^{2}$ Grupo Integrado de Aqüicultura e Estudos Ambientais, Universidade Federal do \\ Paraná, 81531-990, Curitiba, PR, Brazil, ${ }^{3}$ Departado de Ciências Biológicas, Faculdade de ciẽncias, Universidade Estadual Paulista, \\ Bauru, SP, Brazil
}

\begin{abstract}
The impact of shrimp fisheries in tropical regions has become comparable to the world's most intensively exploited temperate shelf ecosystems. The increase in the fishing fleet in south-eastern Brazil and the decrease in landings of profitable shrimp species have contributed to the incorporation of additional species into those fisheries. The goal of the present study is to investigate the influence of environmental factors on the abundance patterns of shrimp communities on the south-eastern coast of Brazil, over a period of two years. Monthly collections were conducted in the Ubatuba and Caraguatatuba regions using a commercial shrimp fishing boat equipped with 'double-rig' nets. Each region was divided into 7 sampling stations up to $35 \mathrm{~m}$ deep. The relationship between the environmental factors and the abundance patterns in the shrimp communities was assessed using a canonical correlation analysis (CCorrA). The first set of variables used during the CCorrA included environmental characteristics and the second set of variables the abundance of the studied species. A total of 374,915 individuals were collected during the present study. Xiphopenaeus kroyeri showed the highest abundance (273,127), followed by Artemesia longinaris $(73,422)$, and Pleoticus muelleri $(15,262)$. In the first root, depth and temperature showed the highest factor loadings ( 0.9 and -0.7$)$ and canonical weights $(0.6$ and -0.4$)$. These environmental factors were strongly associated with the abundance of X. kroyeri (factor loading $=-0.9$ and canonical weight $=-0.9$ ). The second root demonstrated a positive relationship between abundance of $\mathrm{P}$. muelleri and depth, and an inverse association with bottom temperature. The abundance patterns of X. kroyeri and P. muelleri were strongly affected by the water mass South Atlantic Central Water (cold waters $\left.=15^{\circ} \mathrm{C}\right)$, which can lead to a temperature decrease in deeper areas $\left(>_{15} \mathrm{~m}\right)$. Thus, the opposite abundance trend for depth of these species might reflect bathymetric variation in temperature, a clear example of distinct behavioural differences of species of different origins, either tropical (X. kroyeri) or subantarctic (P. muelleri). The low overall association between environmental parameters and shrimp abundance patterns indicates that each studied species might have responded idiosyncratically to environmental variation, such that a general community-level response was not apparent. However, other confounding factors such as intraspecific migration patterns might have also played a role in generating the observed patterns.
\end{abstract}

Keywords: Shrimp, community, variation, Brazil

Submitted 2 May 2007; accepted 4 November 2007

\section{INTRDDUCTIDN}

Human populations are growing along coastlines, as well as the corresponding anthropogenic impact on their natural communities. Gathering accurate information on benthic communities is therefore urgently needed for the proper management and conservation of coastal ecosystems (Bertness, 1999). The exploitation of penaeid coastal shrimps in tropical regions is a very ancient activity that resulted in the current

Corresponding author:

A.L. Castilho

Email: castilho@ibb.unesp.br overexploitation of much of the fishery resources (Garcia \& Le Reste, 1981). The impact of shrimp fisheries in tropical regions has become comparable to the world's most intensively exploited temperate shelf ecosystems, thus causing significant losses in spawning biomass and biodiversity, especially as a consequence of stocks trawling on softbottoms (Pauly \& Christensen, 1995; Pauly et al., 2002).

Shrimp fisheries in south-eastern Brazil target the most profitable species, such as the pink shrimp Farfantepenaeus brasiliensis (Latreille, 1817) and F. paulensis (Pérez-Farfante, 1967), the white shrimp Litopenaeus schmitti (Burkenroad, 1938) and the seabob shrimp Xiphopenaeus kroyeri (Heller, 1862) (Costa et al., 2004; Castro et al., 2005). The recent increase in the fishing fleet and the decrease in landings of 
those species have contributed to the incorporation of additional species into those fisheries, including Artemesia longinaris Bate, 1888 and Pleoticus muelleri (Bate, 1888) (D'Incao et al., 2002; Costa et al., 2004, 2005, 2007; Castilho et al., 2007a). Other penaeoidean species that are habitually found in this region, such as the sicyoniids Sicyonia dorsalis Kingsley, 1878, and S. typica Boeck, 1864 and the penaeid Rimapenaeus constrictus (Stimpson, 1874), are still noncommercial species due to their small size.

Most shrimp species are found in tropical and subtropical regions, with a marked decrease in number towards temperate and cold regions. Their distribution may depend on a variety of environmental factors (Boschi, 2000). Several studies have investigated how the distribution of penaeid shrimps is modulated by variation in ecological parameters, particularly the type of sediment, salinity, depth and temperature (Fransozo et al., 2002, 2004; Costa \& Fransozo, 2004; Costa et al., 2004, 2005, 2007; Castro et al., 2005). However, little is known about how these ecological parameters translate into the abundance patterns at the level of entire shrimp communities. Such knowledge is fundamental, not only to understand the mechanisms underlying shrimp community dynamics, but also to effectively manage shrimp fishery resources.

The goal of the present study is to understand how variation in environmental characteristics affects the abundance patterns of shrimp communities on the south-eastern coast of Brazil using multivariate methods.

\section{MATERIALS AND METHDDS}

Shrimp collections were carried out monthly between July 2001 and June 2003 in two locations-Ubatuba (UB) and Caraguatatuba (CA) - both on the northern coast of the state of São Paulo, south-eastern Brazil (UB: $-23^{\circ} 26^{\prime} 27^{\prime \prime}$ $-45^{\circ} 03^{\prime} 18^{\prime \prime}$; CA: $\left.-23^{\circ} 36^{\prime} 0^{\prime}-45^{\circ} 20^{\prime} 25^{\prime \prime}\right)$. Seven transects were sampled in each location at varying depths $(5,10,15$, $20,25,30$ and $35 \mathrm{~m}$ ). A shrimp-fishing boat equipped with two double-rig nets (mesh size $20 \mathrm{~mm}$ and $15 \mathrm{~mm}$ in the cod end) was used for trawling, which lasted for 30 minutes in each transect, sampling a total area of approximately $18,000 \mathrm{~m}^{2}$. When a given trawl yielded considerable biomass of a given species, a $200 \mathrm{~g}$ random subsample of that species was obtained and examined separately, and the results were extrapolated for that respective species in that trawl.

Five environmental characteristics were recorded at each location, namely: bottom water salinity and temperature, organic matter content, depth, and sediment grain size. A detailed description of the sampling methods and an analysis of environmental parameters during the study period are available elsewhere. Bottom water was sampled using a Nansen bottle. The salinity was measured with an Atago S/1000 optic refractometer, whereas the temperature $\left({ }^{\circ} \mathrm{C}\right)$ was measured using a thermometer attached to the bottle. An ecobathymeter coupled with a GPS was used to record depth (m) at sampling sites. Sediment samples were collected at each station with a Van Veen grab $\left(0.06 \mathrm{~m}^{2}\right)$. In the laboratory, the sediment was dried at $70^{\circ} \mathrm{C}$ for $72 \mathrm{~h}$. For the analysis of grain size composition, two 50-g sub-samples were treated with $250 \mathrm{~mL}$ of a $\mathrm{NaOH}$ $0.2 \mathrm{~N}$ solution, stirred for five minutes to release silt and clay particles, and then rinsed on a $0.063-\mathrm{mm}$ sieve.

Sediments were sieved through $2 \mathrm{~mm}$ (gravel); $2.0-$ $1.01 \mathrm{~mm}$ (very coarse sand); $1.0-0.51 \mathrm{~mm}$ (coarse sand);
$0.50-0.26 \mathrm{~mm}$ (medium sand); 0.25-0.126 mm (fine sand); and $0.125-0.063 \mathrm{~mm}$ (very fine sand); smaller particles were classified as silt-clay. Grain size categories followed the American standard, and fractions were expressed on the phi ( $\phi)$ scale, i.e. using the formula $\phi=-\log _{2} d$, where $d=$ grain diameter (mm) (Tucker 1988), e.g. $-1=\phi<0$ (very coarse sand); $0=\phi<1$ (coarse sand); $1=\phi<2$ (intermediate sand); $2=\phi<3$ (fine sand); $3=\phi<4$ (very fine sand) and $\phi \geq 4$ (silt + clay). Finally, $\phi$ was calculated by cumulative particle-size curves plotted on a computer using the $\phi$ scale, with values corresponding to the 16th, 5oth and 84 th percentiles being used to determine the mean diameter of the sediment using the formula $\mathrm{Md}=\left(\phi_{16}+\right.$ $\left.\phi_{50}+\phi_{84}\right) / 3$. Finally, $\phi$ was calculated.

The organic matter content (\%) was obtained by ashweighing: 3 aliquots of $10 \mathrm{~g}$ each per transect were placed in porcelain crucibles, heated for $3 \mathrm{~h}$ at $500^{\circ} \mathrm{C}$, and then weighed again.

The relationship between the environmental factors and the abundance patterns in the shrimp communities was assessed using a canonical correlation analysis (CCorrA). This analysis is a multivariate statistical procedure that directly measures the strength of relationships between two sets of variables. The first set of variables used during the CCorrA included the environmental characteristics (bottom water salinity and temperature, organic matter content, depth, and $\phi$ ), whereas the second set of variables included the abundance of the studied species (L. schmitti, R. constrictus, S. dorsalis, P. muelleri, A. longinaris, F. brasiliensis, $F$. paulensis and $X$. kroyeri). Sicyonia laevigata Stimpson, 1871 and S. typica were also recorded in the study areas, yet were not incorporated into the CCorrA because they were present in less than $10 \%$ of the monthly samples in either site (Cuesta et al., 2006).

Three alternative data transformations were tested with respect to their capacity to improve the normality of the data: $1 / x, \ln (1+x)$, and $\operatorname{sqrt}(\mathrm{x})$, and the most appropriate transformation was chosen based on the lowest KolmogorovSmirnov D. Using this criterion, the abundance of $R$. constrictus, S. dorsalis, P. muelleri, F. brasiliensis, and X. kroyeri was sqrt-transformed, whereas the abundance of $A$. longinaris and the levels of organic matter were ln-transformed prior to the analyses. However, it is important to point out that CCorrA is fairly robust to violations in this assumption, and an analysis of the same dataset with untransformed variables provided similar results, except for a slightly lower fit of the model to the data (not shown).

All samples from both locations were incorporated into the same analysis. This approach is justified given that the goal of the present study is not to characterize each sampling location. Instead, by including the widest possible variation in environmental parameters, one would expect that the effects of these parameters on the shrimp communities would become more apparent.

\section{RESULTS}

Variation in the environmental parameters and in species abundance is shown in Table 1 . The range of variation recorded during this study is likely to encompass most of the conditions found throughout the geographical range of the studied species. 
Table 1. Observed variation in the environmental variables and in the number of captured individuals of each species in the present study.

\begin{tabular}{lrrl}
\hline & Mean & \multicolumn{1}{c}{ SD } & Range \\
\hline Environmental variables & & & \\
Bottom temperature $\left({ }^{\circ} \mathrm{C}\right)$ & 22.00 & 2.52 & $(15.00-29.50)$ \\
Bottom salinity (ppt) & 35.21 & 1.15 & $(30.00-37.00)$ \\
Depth (m) & 20.00 & 9.82 & $(4.33-36.07)$ \\
Organic matter content (\%) & 4.03 & 3.08 & $(0.70-17.40)$ \\
$\phi$ & 3.66 & 1.43 & $(0.24-6.42)$ \\
& & & \\
Species variables & & & \\
Artemesia longinaris & 218.52 & 923.61 & $(\mathrm{o}-10465.69)$ \\
Farfantepenaeus brasiliensis & 5.01 & 13.96 & $(\mathrm{o}-116.00)$ \\
Farfantepenaeus paulensis & 0.59 & 1.44 & $(\mathrm{o}-16.00)$ \\
Litopenaeus schmitti & 4.98 & 12.00 & $(\mathrm{o}-88.00)$ \\
Pleoticus muelleri & 45.42 & 144.38 & $(\mathrm{o}-1199.69)$ \\
Rimapenaeus constrictus & 17.46 & 54.38 & $(\mathrm{o}-738.40)$ \\
Sicyonia dorsalis & 10.96 & 51.92 & $(\mathrm{o}-739.00)$ \\
Xiphopenaeus kroyeri & 812.88 & 1785.61 & $(\mathrm{o}-19522.00)$ \\
\hline
\end{tabular}

$\mathrm{SD}$, standard deviation

A total of 374,915 individuals were collected during the present study. Xiphopenaeus kroyeri showed the highest abundance $(273,127$ individuals), followed by A. longinaris $(73,422$ individuals) and P. muelleri (15,262 indoviduals), with each of those three species accounting for $73 \%, 20 \%$, and $4 \%$ of all captured individuals, respectively.

The CCorrA resulted in a canonical correlation coefficient of $0.59(P<0.000001)$, with $100 \%$ of the variance being extracted from the dataset of the environmental variables (total redundancy of $23.02 \%$ ), whereas $69.35 \%$ of the variance was extracted from the dataset with information on the community composition (total redundancy of $12.07 \%$ ). The first four roots were statistically significant (Table 2). However, the first canonical root accounted for more than three times the explained variance than the second root $(27.3 \%$ and $8.6 \%$, respectively), with little difference in the explained variance between roots 2 and 4 .

The canonical factor loadings (the correlation between the canonical and the original variables) and the canonical weights (the partial correlations of the original variables with respect to the canonical root) for the first three roots are shown in Table 3. The environmental variable with the highest factor loading in the first root is depth (o.89), followed by $\phi$ and temperature, which show similar loadings of opposite signs in relation to depth $(-0.71$ and -0.72 , respectively). However, given the high level of covariance among these variables, an inspection of their canonical weights can provide an indication of their individual contributions controlling for other variables. Indeed, the factor loading of $\phi$ seems to be best explained by covariance with other variables, with little direct contribution to the variation in the dataset $\left(\mathrm{CW}_{\phi}=-0.07\right)$. On the other hand, both depth and temperature show high and opposite canonical weights,

Table 2. Results of canonical correlation analysis of shrimp communities in south-eastern Brazil. See text for details.

\begin{tabular}{lllrrl}
\hline Root removed & Eigenvalues & Canonical R & $\chi^{2}$ & df & p \\
\hline 1 & 0.356 & 0.522 & 164.15 & 28 & 0.000001 \\
2 & 0.272 & 0.293 & 59.99 & 18 & 0.000002 \\
3 & 0.086 & 0.230 & 30.55 & 10 & 0.0007 \\
4 & 0.053 & 0.195 & 12.68 & 4 & 0.01 \\
\hline
\end{tabular}

df, degrees of freedom.
Table 3. Canonical factor loadings and weights based on the canonical correlation analyses of the relationship between environmental characteristics and shrimp abundance patterns.

\begin{tabular}{|c|c|c|c|c|c|c|}
\hline & \multicolumn{3}{|c|}{$\begin{array}{l}\text { Canonical factor } \\
\text { loadings }\end{array}$} & \multicolumn{3}{|c|}{ Canonical weights } \\
\hline & Root 1 & Root 2 & Root 3 & Root 1 & Root 2 & Root 3 \\
\hline Bottom temperature & -0.728 & -0.520 & 0.322 & -0.386 & -0.760 & 0.315 \\
\hline Bottom salinity & 0.348 & -0.018 & -0.561 & 0.086 & -0.225 & -0.586 \\
\hline Depth & 0.894 & -0.087 & 0.147 & 0.570 & 0.289 & 0.757 \\
\hline $\begin{array}{l}\text { Organic matter } \\
\text { content }\end{array}$ & -0.547 & 0.455 & -0.423 & -0.231 & 0.088 & -0.814 \\
\hline$\phi$ & -0.715 & 0.611 & 0.118 & -0.074 & 0.958 & 0.963 \\
\hline Artemesia longinaris & -0.104 & 0.331 & 0.299 & -0.241 & -0.070 & 0.435 \\
\hline $\begin{array}{c}\text { Farfantepenaeus } \\
\text { brasiliensis }\end{array}$ & -0.014 & -0.222 & 0.183 & -0.135 & -0.116 & 0.333 \\
\hline $\begin{array}{l}\text { Farfantepenaeus } \\
\text { paulensis }\end{array}$ & -0.105 & -0.308 & -0.238 & -0.086 & -0.268 & -0.407 \\
\hline Litopenaeus schmitti & -0.442 & 0.403 & 0.388 & -0.090 & 0.454 & 0.493 \\
\hline Pleoticus muelleri & 0.092 & 0.744 & 0.070 & 0.451 & 0.740 & 0.095 \\
\hline $\begin{array}{l}\text { Rimapenaeus } \\
\text { constrictus }\end{array}$ & -0.230 & 0.210 & -0.211 & 0.165 & -0.166 & -0.014 \\
\hline Sicyonia dorsalis & -0.303 & 0.587 & -0.639 & -0.339 & 0.410 & -0.794 \\
\hline $\begin{array}{l}\text { Xiphopenaeus } \\
\text { kroyeri }\end{array}$ & -0.910 & 0.124 & 0.114 & -0.899 & -0.200 & 0.030 \\
\hline
\end{tabular}

indicating that the first root reflects most strongly the variation in these two variables.

The second root reflects an inverse relationship between $\phi$ and bottom temperature, as shown by their high factor loadings ( 0.61 and -0.52 , respectively), and specially their canonical weights ( 0.96 and -0.76 , respectively). Finally, the third root reflects an inverse relationship between $\phi$ and organic matter content, with the latter showing a canonical weight of -0.81 .

There was little consistency in the response of the studied shrimp species to variation in environmental variables. The first root was strongly associated with the abundance of $X$. kroyeri, as revealed by its high factor loading $(-0.91)$ and canonical weight $(-0.89)$, yet no other species showed values more extreme than \pm 0.5 for either statistic. Similar associations were found between $P$. muelleri and root 2, and between $S$. dorsalis and root 3. Interestingly, the variation in abundance of L. schmitti, R. constrictus, A. longinaris, F. brasiliensis and $F$. paulensis were not well-described by any of the first three roots in the model.

\section{DISCUSSIDN}

Benthic communities are affected by a variety of biotic and abiotic parameters, including sea floor characteristics, food availability, tidal and sea-level patterns, community composition, prey-predator relationships, interactions among species, and the reproductive strategies of their component species (Lenihan \& Micheli, 2001). These ecological variables are reflected in the evolutionary adaptations of species and their large-scale biogeographical patterns (Harley et al., 2006). The biogeographical provinces of the south-western Atlantic Ocean begin at latitudes $43-44^{\circ} \mathrm{S}$, spanning the continental shelves of Argentina, Uruguay and southern Brazil. On the other hand, the coastal region between $23^{\circ}$ and $35^{\circ}$ $\mathrm{S}$ is a transitional area characterized by processes of mixing 
and instability of the water masses, with presence of both eurythermal and euryhaline species (Boschi, 2000).

The south-eastern Brazilian coast is strongly affected by two water masses: the Coastal Water (CW) and Tropical Water (TW). The effects of these water masses are more pronounced during autumn and winter, when temperature and salinity levels increase to over $21^{\circ} \mathrm{C}$ and 35 , respectively. Another water mass, the South Atlantic Central Water (SACW), intrudes throughout late spring and summer, causing decreases in temperature $\left(<20^{\circ} \mathrm{C}\right)$ and bottom salinity $(<35)$. The incursion of the TW into the uppermost water layers and the dislocation of the $\mathrm{CW}$ towards the ocean during the autumn and winter cause vertical mixing and thus eliminate the existing seasonal thermocline, causing the SACW to recede towards the offshore region (Castro-Filho et al., 1987; Castilho et al., 2007a, b). The intrusion of the SACW causes considerable changes to the resident communities, either positive or negative. Some species show abundance peaks associated with the arrival of the SACW, as in the case of the crabs Portunus spinicarpus (Stimpson, 1871), Leurocyclus tuberculosus (Edwards \& Lucas, 1843) and Stenocionops spinosissima (Saussure, 1857). Therefore, the south-south-east shelf represents an area of intense faunistic transition, including species ranging from tropical to subantarctic (Boschi, 2000).

In addition to corroborating the scenario described above, our results indicate that variation in the abundance of $X$. kroyeri and $P$. muelleri was influenced by variation in temperature. The influence of the SACW (cold waters $=15^{\circ} \mathrm{C}$ ) for $X$. kroyeri is responsible for a decrease in the number of collected individuals. Similar results were found by Fransozo et al. (2002), Castro et al. (2005) and Costa et al. (2007), suggesting that temperatures below $21^{\circ} \mathrm{C}$ may be limiting for this species. The inverse relationship of abundance and temperature was verified to $P$. muelleri, which together with A. longinaris, can be considered as indicator species of the inbound cold water (Boschi, 1969, 1989; Gavio \& Boschi, 2004; Fransozo et al., 2004; Costa et al., 2004, 2005). Although both species migrate to the south-western shore of Brazil during the intrusions of the SACW, the present study found little association between temperature and the abundance of $A$. longinaris. These results corroborate the hypothesis of Costa et al. (2005) that A. longinaris can cope with more pronounced thermal oscillations and migrates farther north along the Brazilian coast than P. muelleri.

Several authors have suggested that the distribution of penaeoid shrimps is strongly modulated by the texture and the organic content of the substrate (Boschi, 1969; Dall et al., 1990; Nakagaki et al., 1995). However, those factors did not exert a consistent influence on the studied community as a whole. Although the second root indicated an inverse relationship between $\phi$ and bottom temperature and the third root reflected an inverse relationship between $\phi$ and organic matter content, most species showed weak loadings on those roots, except for P. muelleri and $S$. dorsalis on the first and second roots, respectively.

The abundance patterns of $X$. kroyeri and P. muelleri were strongly affected by water depth, but in different directions: $X$. kroyeri was observed in shallow waters, whereas $P$. muelleri was more characteristic of higher depths. A similar result was obtained by Costa (2002) in the Ubatuba region, where $95 \%$ of the captures of $X$. kroyeri were carried out in inshore waters (depth $\leq 15 \mathrm{~m}$ ). Also, Costa et al. (2004) observed a positive association between the abundance of $P$. muelleri and water depth in the Ubatuba region, with most captures occurring at depths greater than $9 \mathrm{~m}$. According to Castro-Filho et al. (1987), CW can affect shallow waters up to $25 \mathrm{~m}$ in depth. In this water mass, salinity is always below 36 and temperature above $20^{\circ} \mathrm{C}$. Also, the SACW can lead to a temperature decrease in deeper areas, occasionally reaching more coastal grounds. Thus, the inverse abundance variation for depth of these species might reflect bathymetric variation in temperature, a clear example of distinct behavioural differences of species of different origins, either tropical (X. kroyeri) or subantarctic (P. muelleri). Thus, depth and temperature were among the main factors underlying the abundance patterns of X. kroyeri and P. muelleri in the period and regions studied.

Two hypotheses are proposed to explain the low association between the remaining environmental factors and the abundance patterns of the studied species. First, it is possible that the amplitude of the variation in the environmental conditions was not sufficient to allow for their effects to be apparent. One such condition is salinity, given that the samples were only conducted in the marine environment. For instance, Gunter et al. (1964) showed a significant influence of salinity on shrimp abundance patterns in southern Texas by sampling salinity levels from 5 to 35 . Alternatively, a general description of how shrimp abundance responds to environmental changes might not be realistic because each shrimp species may in fact display its own idiosyncratic environmental preferences and constraints.

Alternatively, variation in the abundance patterns of the studied species might result from the influence of other biotic and abiotic factors that were not considered in the present study, such as intraspecific migration patterns. According to Dall et al. (1990), juvenile and subadult shrimps of the species F. brasiliensis, F. paulensis and $L$. schmitti are most commonly found in inshore regions such as bays until they reach gonadal maturity, when they migrate to offshore regions during the breeding and spawning periods. It is important to note that, according to Chagas-Soares et al. (1995), the south littoral of São Paulo state (Cananéia region) is a rich nursery ground for the shrimp L. schmitti and Farfantepenaeus spp. Costa (2002) suggested that subadults of L. schmitti captured in Ubatuba had in fact immigrated from another region, such as Cananéia. Therefore, the variation in abundance of those species might at times be related to the physiological demands associated with their reproductive behaviour, such as the migration of adults for copulation and spawning, rather than to environmental factors responsible for the permancence of those species in the studied shores.

Penaeid shrimp in south-eastern Brazil also seem to adjust their reproductive phenology to variation in phytoplankton, particularly the increase in their abundance during the spring and summer resulting from the upwelling of the SACW (Costa \& Fransozo, 2004; Castilho et al., 2007a, b). In addition, the shrimp communities in the present study include both tropical and subantartic species (Boschi, 2000), which might display idiosyncratic responses to environmental factors and food availability. Future studies on habitat selection, focusing specifically on the spawning sites and the patterns of juvenile recruitment on the northern coast of São Paulo, are specially relevant to clarify the presented hypothesis on the relationship between environmental variation and the abundance of the studied species. 


\section{ACKNDWLEDGEMENTS}

The authors are grateful to Fapesp, $\mathrm{CNPq}$ for financing part of this work, to the NEBECC members for helping during samplings and laboratory activities. We thank the Instituto Brasileiro do Meio Ambiente e dos Recursos Naturais Renováveis (IBAMA) for granting permission to collect the shrimps.

\section{REFERENCES}

Bertness M.D. (1999) The ecology of Atlantic shorelines, 1st edn. Sunderland, Massachusetts: Sinauer Associates, Inc.

Boschi E.E. (1969) Estudio biológico pesquero del camarón Artemesia longinaris Bate de Mar del Plata. Boletín del Instituto de Biología Marina 18, 1-47.

Boschi E.E. (1989) Biologia pesquera del lagostino del patagonico de Argentina (Pleoticus muelleri). Contribuciones del Instituto Nacional de Investigación y Desarrollo Pesquero 646, 5-71.

Boschi E.E. (2000) Species of decapod crustaceans and their distribution in the marine zoogeographic provinces. Revista de Investigación $y$ Desarrollo Pesquero 13, 7-136.

Castilho A.L., Costa R.C., Fransozo A. and Boschi E.E. (2007a) Reproductive pattern of the South American endemic shrimp Artemesia longinaris (Decapoda, Penaeidae), off the coast of São Paulo state, Brazil. Revista de Biología Tropical. in press.

Castilho A.L., Gavio M.A., Costa R.C., Boschi E.E., Bauer R.T. and Fransozo A. (2007b) Latitudinal variation in population structure and reproduction pattern of the endemic South American shrimp Artemesia longinaris (Decapoda: Penaeoidea). Journal of Crustacean Biology 27. in press.

Castro R.H., Costa R.C., Fransozo A. and Mantelatto F.L.M. (2005) Population structure of seabob shrimp Xiphopenaeus kroyeri (Heller, 1862) (Crustacea: Penaeoidea) in the littoral of São Paulo, Brazil. Scientia Marina 69, 105-112.

Castro-Filho B.M., Miranda L.B. and Myao S.Y. (1987) Condições hidrográficas na plataforma continental ao largo de Ubatuba: variações sazonais e em média escala. Boletim do Instituto Oceanográfico 35, $135-151$.

Chagas-Soares F., Pereira O.M. and Santos E.P. (1995) Contribuição ao ciclo biológico de Penaeus schmitti Burkenroad, 1936, Penaeus brasiliensis Latreille, 1817 e Penaeus paulensis Pérez-Farfante, 1967, na região Lagunar-Estuarina de Cananéia, São Paulo, Brasil. Boletim do Instituto de Pesca 22, 49-59.

Costa R.C. (2002) Biologia e Distribuição Ecológica das Espécies de Camarões Dendrobranchiata (Crustacea: Decapoda) na Região de Ubatuba (SP). PhD thesis, Universidade Estadual Paulista, Botucatu, Brazil.

Costa R.C. and Fransozo A. (2004) Abundance and ecologic distribution of the shrimp Rimapenaeus constrictus (Crustacea: Penaeidae) in the northern coast of São Paulo State, Brazil. Journal of Natural History $38,901-912$.

Costa R.C., Fransozo A., Castilho A.L. and Freire F.A.M. (2005) Annual, seasonal and spatial variation of abundance of the shrimp Artemesia longinaris (Decapoda: Penaeoidea) in a south-eastern region of Brazil. Journal of the Marine Biological Association of the United Kingdom 85, 107-112.

Costa R.C., Fransozo A., Freire F.A.M. and Castilho A.L. (2007) Abundance and ecological distribution of the 'sete-barbas' shrimp Xipohpenaeus kroyeri (Heller, 1862) (Decapoda: Penaeoidea) in three bays of the Ubatuba region, South-eastern Brazil. Gulf and Caribbean Research 19, 33-41.
Costa R.C., Fransozo A. and Pinheiro A.P. (2004) Ecological distribution of the shrimp Pleoticus muelleri (Bate, 1888) (Decapoda: Penaeoidea) in southeastern Brazil. Hydrobiologia 529, 195-203.

Cuesta J.A., González-Ortegón E., Rodríguez A., Baldó F. Vilas C. and Drake P. (2006) The decapod crustacean community of the Guadalquivir estuary (SW Spain): seasonal and inter-year changes in community structure. Hydrobiologia 557, 85-95.

Dall W., Hill B.J., Rothlisberg P.C. and Staples D.J. (1990) The biology of the Penaeidae. In Blaxter J.H.S and Southward A.J. (eds) Advances in marine biology. San Diego: Academic Press, pp. 1-489.

D'Incao F., Valentini H. and Rodrigues L.F. (2002) Avaliação da pesca de camarões nas regiões Sudeste e Sul do Brasil. Atlântica 24, 103-116.

Fransozo A., Costa R.C., Castilho A.L. and Mantelatto F.L.M. (2004) Ecological distribution of the shrimp 'barba-ruça' Artemesia longinaris (Decapoda: Penaeidae) in Fortaleza Bay, Ubatuba, Brazil. Revista de Investigación y Desarrollo Pesquero 16, 45-53.

Fransozo A., Costa R.C., Mantelatto F.L.M., Pinheiro M.A.A. and Santos S. (2002) Composition and abundance shrimp species (Penaeidea and Caridea) in Fortaleza bay, Ubatuba, São Paulo, Brasil. In Briones E.E. and Alvarez F. (eds) Modern approaches to the study of Crustacea. México: Kluwer Academic Press, pp. 117-125.

Garcia S. and Le Reste L. (1981) Life cycles, dynamics, exploitation, and management of coastal penaeid shrimp stocks. FAO Fisheries Technical Papers 203, 1-215.

Gavio M.A. and Boschi E.E. (2004) Biology of the shrimp Artemesia longinaris Bate, 1888 (Crustacea: Decapoda: Penaeidae) from Mar del Plata coast, Argentina. Nauplius 12, 83-94.

Gunter G., Christmas J.Y. and Killebrew R. (1964) Some relations of salinity to population distributions of motile estuarine organisms, with special reference to penaeid shrimp. Ecology 45, 181-185.

Harley C.D.G., Hughes A.R., Hultgren K.M., Miner B.G., Sorte C.J.B., Thornber C.S., Rodriguez L.F., Tomanek L. and Williams S.L. (2006) The impacts of climate change in coastal marine systems. Ecology Letters 9, 228-241.

Lenihan H.S. and Micheli F. (2001) Soft-sediment communities. In Bertness M.D. et al. (eds) Marine community ecology. Sunderland, Massachusetts: Sinauer Associates, pp. 253-287.

Nakagaki J.M., Negreiros-Fransozo M.L. and Fransozo A. (1995) Composição e abundância de camarões marinhos (Crustacea; Decapoda: Penaeidae) na Enseada de Ubatuba, Ubatuba, Brasil. Arquivos de Biologia e Tecnologia 38, 583-591.

Pauly D. and Christensen V. (1995) Primary production required to sustain global fisheries. Nature 374, 255-257.

Pauly D., Christensen V., Guénette S., Pitcher T.J., Sumaila U.R., Walters C.J., Watson R. and Zeller D. (2002) Towards sustainability in world fisheries. Nature 418, 689-695.

and

Tucker M. (1988) Techniques in sedimentology. Boston, US and Oxford, UK: Blackwell Scientific Publications, pp. 1-394.

Correspondence should be addressed to:

Antonio L. Castilho

NEBECC (Group of Studies on Crustacean Biology, Ecology and Culture)

Departamento de Zoologia

Universidade Estadual Paulista

18618-ooo, Botucatu

São Paulo

Brazil

email: castilho@ibb.unesp.br 